\title{
The Teaching of Blissymbols as a Bridge into Literacy for Children with Cognitive Impairments: A Comparison of Two Training Approaches
}

\author{
Enid Moolman and Erna Alant \\ Centre for Augmentative and Alternative Communication, Department of Communication Pathology, \\ University of Pretoria
}

\section{SUMMARY}

This study compares the learning of Blissymbols by six mildly cognitively impaired children by means of a global and an analytic approach. Training consisted of two stages. The first was the training of eight compound symbols and the second the training of seven single configuration symbols. The study concludes that Blissymbols as an entrance into literacy can be taught successfully to cognitively impaired individuals by means of either an analytic or a global approach. The analytic approach seems to have greater long-term benefits, as the subjects instructed by the analytic approach consistently performed better in the generalization and re-evaluation procedures. The analytic approach, however, was much more time consuming than the global approach in terms of the length of training required. The implications for literacy development and augmentative and alternative communication systems are discussed.

\section{OPSOMMING}

Hierdie studie vergelyk, deur middel van 'n globale en 'n analitiese benadering, die aanleer van Blissimbole deur ses kinders elk met geringe hognitiewe gestremdheid. Opleiding het uit twee fases bestaan, waarvan die eerste die opleiding van agt saamgestelde simbole behels het en die tweede die opleiding van sewe enkel-element simbole.

Die bevindinge dui daarop dat Bliss-simbole suksesvol deur individue met geringe kognitiewe gestremdheid aangeleer kan word deur middel van of 'n globale of 'n analitiese benadering, alhoewel die verskille tussen resultate nie statisties betekenisvol is nie. Dit het egter geblyk dat die analitiese opleidingsmetode sekere langtermynvoordele ingehou het, aangesien daar'n konstante tendens vir die analitiese groep was om beter te vaar met die veralgemenings-en die herevaluasie-prosedures. Wat betref die lengte van opleiding was die analitiese opleidingsmetode egter baie meer tydrowend as die globale metode. Die implikasies vir die ontwikkeling van geletterdheid en aanvullende en alternatiewe kommunikasie is bespreek.

KEY WORDS: Blissymbols, literacy, global approach, analytic approach

\section{INTRODUCTION}

For many years it was believed that cognitively impaired individuals cannot acquire any literacy skills as they seem to be unable to learn to read and write. Studies by researchers such as Sterick (1979), Folk and Campbell (1978), and Raver and Dwyer (1986), however, demonstrate that the cognitively impaired child can, in fact, learn to read and write. Nevertheless, it is worth noting that cognitively impaired individuals tend to achieve reading levels that are below their cognitive levels (Buttery \& Creekmore, 1985). The latter fact has led to a re-evaluation of instructional approaches for teaching literacy skills to the cognitively impaired population as well as our definition of literacy. As a result, the use of augmentative and alternative communication strategies as a bridge to literacy has come under scrutiny.

Many view literacy in a restricted sense, namely as the ability to read and write. In contrast with this limited view,
Miller (1990:2) states that "... becoming literate involves learning how to manipulate various bodies of knowledge ... and because being literate involves a way of thinking, literacy becomes entwined with how and what people know. One who is literate is conversant with what is going on in the world." Two models of teaching literacy skills can therefore be distinguished. We can either teach the child the technical skill of reading and writing (model 1), or social skills, in other words, equip the child to become a literate participant in society (model 2 ). The problem with teaching the child only the technical skills of reading/writing is that this is neither meaningful nor functional and the child is unable to identify with it. Literacy can be viewed as a systematic progression from recognizing pictures to the use of an abstract symbol system such as normal orthography. To become literate, an individual must be visually directed, able to extract meaning, and able to interpret symbols on different levels of abstractness.

Initially, Blissymbols were used primarily to augment speech in individuals with severe speech and communication problems. It was soon realized, however, that Blissymbols could play an important role in bridging the 
gap between pictures and print, as Blissymbols are concept-based and thus easier to learn than normal orthography (Luftig \& Bersani, 1985). In addition, the child can be prepared for the processing of print through the use of Blissymbols, as their use includes many of the skills necded for normal orthography. The ability to synthesize elements to makc a word, and the ability to integrate and process a number of symbols that communicate an idea are important elements in preparing a child for reading (Archer, 1977). These skills can be facilitated by the use of Blissymbols, depending on the nature of the instructional approach. As in the teaching of reading, two main approaches for the teaching of Blissymbols can be identified, namely a global and an analytic approach. A global approach entails training of the entire symbol without any reference to the symbol elements. An analytic approach, on the other hand, requires an explanation of the meaning of each of the elements within a compound symbol. If a child is therefore taught Blissymbols by means of an analytic approach, he/she might be able to transfer this analytic skill to normal orthography (Alant, 1994; McNaughton, 1993).

Shepherd and Haaf (1992) compared the global and analytic training approaches by training individuals who were not disabled, and they found that an analytic training approach could have several advantages over a global approach. Results obtained on cognitively normal individuals, however, cannot simply be transferred to the cognitively impaired population. The research discussed in this article therefore serves as a preliminary study to investigate the effects of the global and analytic approaches to Blissymbol training for cognitivcly impaired individuals. It is important for us to determine the effect of these two training approaches as it might be significant in our clinical application.

\section{METHOD}

\section{AIMS}

The primary aim of this study was to compare two training approaches in the teaching of Blissymbols to cognitively impaired children. The objectives of this study were:

to teach specific symbols to Group 1 by means of a global approach

- to teach the same symbols to Group 2 by means of an analytic approach

- to compare the results obtained by these two groups with reference to:

* the number of presentations required to reach the criterion

* the number of minutes required to reach the criterion

* the \% of symbols correctly analysed and synthesized during a generalization procedure

* the $\%$ of symbols correctly identified after a set period without any exposure (re-evaluation procedure)

- to do a qualitative analysis of individual subject's performances in symbol acquisition with regard to:

* ease of acquisition

* nature and complexity of symbols

\section{SUBJECTS}

Pupils enrolled at a school for cognitively impaired chil- dren were selected according to specified selection criteria. A total of eight subjects was initially selected, but due to numerous absences and poor co-operation (which, it was felt, could contribute to invalid test results), subjects 1 and 8 were dropped from the study. Six subjects ( 4 male, 2 female) were thus used in this study. All subjects presented with mild cognitive impairment, with an IQ score of between 50 and 65 , and their chronological ages ranged from 7 to 10 years. To check that subjects were unable to read the Blissymbols, subjects who had a functional reading vocabulary of less than 40 words were selected and subjects had to have had no prior familiarity with Blissymbols. All subjects' speech was intelligible most of the time in a context unknown to the listener. None of the subjects suffered from visual, speech, hearing or obvious emotional problems that would have interfered with their performance in the tasks required in this study. All subjects were native Afrikaans speakers and camc from families who enjoyed middle to high socio-economic status (Moolman, 1994). Subject characteristics are outlined in Table 1.

\section{SUBJECT SELECTION PROCEDURES}

All subjects had to comply with the criteria previously discussed. For the initial selection of the eight subjects, a pre-evaluation of certain skills was administered (sec Table 2 and Appendix D for a detailed outline). Subjects were then paired with one another according to the results obtained during the pre-evaluation. General level of functioning (which included IQ score) as judged by the teacher and the local occupational therapist, was considered to be an important aspect for the pairing process. Subjects were further paired according to their receptive language, visual perception and reading skills.

Subject 4 was paired with subject 2 , subject 3 with 7 and subject 5 with 6 . After subjects had been paired, they were randomly divided into two groups, with each group having the same number of subjects, with more or less the same level of skills. Subjects in Group 1 (subjects 3, 4,5) were trained by means of a global training approach and subjects from Group 2 (subjects $7,6,2$ ) by means of an analytic training approach.

Table 2 provides a description of the paired subjects' performances on the different aspects used for pairing.

\section{RESEARCH DESIGN}

A quasi-experimental design was selected for this study as a tightly controlled experimental design in which two groups would be totally comparable would be impossible due to the diversity of children with cognitive impairments. For the purpose of this study six children were identified (three in a group). Each child in Group 1 was paired with another in Group 2. Although pairing was a difficult process within this context, the teachers and therapists at the school agreed that on a functional level these two groups were comparable.

\section{MATERIAL AND APPARATUS USED DURING THE PRE-EVALUATION.PHASE}

The tests and material used to assess the subjects' reading, visual perception, level of functioning and receptive language during the pre-evaluation, are outlined in Table 3 . All the tests and material used during the pre-evaluation are, however, not discussed here due to restricted 
TABLE 1. Subject characteristics

\begin{tabular}{|c|c|c|c|c|c|c|}
\hline Characteristics & $\begin{array}{l}\text { Subject } 2 \\
\text { (Group 2) }\end{array}$ & $\begin{array}{l}\text { Subject } 3 \\
\text { (Group 1) }\end{array}$ & $\begin{array}{l}\text { Subject } 4 \\
\text { (Group 1) }\end{array}$ & $\begin{array}{l}\text { Subject } 5 \\
\text { (Group 1) }\end{array}$ & $\begin{array}{l}\text { Subject } 6 \\
\text { (Group 2) }\end{array}$ & $\begin{array}{l}\text { Subject } 7 \\
\text { (Group 2) }\end{array}$ \\
\hline $\begin{array}{l}\text { Chronological } \\
\text { age (years and } \\
\text { months) }\end{array}$ & 8,5 & 8,6 & 9,3 & 7,3 & 7,6 & 8,11 \\
\hline $\begin{array}{l}\text { Socio-economic } \\
\text { status }\end{array}$ & middle-high & middle-high & high & middle & high & middle \\
\hline Hearing & normal & normal & normal & normal & normal & normal \\
\hline $\begin{array}{l}\text { Vision: general } \\
\text { description }\end{array}$ & adequate & $\begin{array}{l}\text { glasscs, } \\
\text { adequate }\end{array}$ & adequate & $\begin{array}{c}\text { short-sighted, } \\
\text { adequate }\end{array}$ & adequate & $\begin{array}{l}\text { glasses, } \\
\text { adequate }\end{array}$ \\
\hline Gender & male & female & male & female & male & male \\
\hline Home language & Afrikaans & Afrikaans & Afrikaans & Afrikaans & Afrikaans & Afrikaans \\
\hline $\begin{array}{l}\text { Intelligence } \\
\text { quotient*: }\end{array}$ & $\begin{array}{c}59 \\
(1991) \\
\end{array}$ & $\begin{array}{c}50 \\
(1991) \\
\end{array}$ & $\begin{array}{c}64 \\
(1990) \\
\end{array}$ & $\begin{array}{c}63 \\
(1992) \\
\end{array}$ & $\begin{array}{c}64 \\
(1992) \\
\end{array}$ & $\begin{array}{c}55 \\
(1991) \\
\end{array}$ \\
\hline Diagnosis & $\begin{array}{l}\text { Cognitive } \\
\text { impairment }\end{array}$ & $\begin{array}{c}\text { Down } \\
\text { syndrome }\end{array}$ & $\begin{array}{l}\text { Micro- } \\
\text { cephaly }\end{array}$ & $\begin{array}{c}\text { Diffuse brain } \\
\text { damage }\end{array}$ & $\begin{array}{l}\text { Cognitive } \\
\text { impairment }\end{array}$ & $\begin{array}{c}\text { Cognitive } \\
\text { impairment }\end{array}$ \\
\hline Medical problems & no cpilepsy & no epilepsy & no epilepsy & no epilepsy & no epilepsy & no epilepsy \\
\hline $\begin{array}{l}\text { Prior exposure } \\
\text { to Bliss }\end{array}$ & none & none & none & none & none & none \\
\hline $\begin{array}{l}\text { Emotional } \\
\text { state }\end{array}$ & $\begin{array}{l}\text { no obvious } \\
\text { problems }\end{array}$ & $\begin{array}{l}\text { no obvious } \\
\text { problems }\end{array}$ & $\begin{array}{l}\text { no obvious } \\
\text { problems }\end{array}$ & $\begin{array}{l}\text { no obvious } \\
\text { problems }\end{array}$ & $\begin{array}{c}\text { no obvious } \\
\text { problems }\end{array}$ & $\begin{array}{c}\text { minimal } \\
\text { autistic }\end{array}$ \\
\hline
\end{tabular}

Key to Table 1:

- Group 1:

Subjects taught by global training approach

- Group 2:

Subjects taught by analytic training approach

- Chronological age: The age recorded in years and months at the commencement of the pre-evaluation phase

* Intelligence quotient: The year in which the IQ test was administered is included in brackets.

TABLE 2. Criteria used for pairing subjects

\begin{tabular}{|c|c|c|c|c|c|c|}
\hline \multirow{2}{*}{$\begin{array}{l}\text { Criteria } \\
\text { used for } \\
\text { pairing } \\
\text { Subjects }\end{array}$} & \multicolumn{2}{|c|}{ Pair 1} & \multicolumn{2}{|c|}{ Pair 2} & \multicolumn{2}{|c|}{ Pair 3} \\
\hline & $\begin{array}{c}\text { S2 }_{!} \\
\text {(Groụp 2) }\end{array}$ & $\stackrel{\text { S4 }}{(\text { Group 1) }}$ & $\begin{array}{c}\text { S7 } \\
\text { (Group 2) }\end{array}$ & $\begin{array}{c}\text { S3 } \\
(\text { Group 1) }\end{array}$ & $\begin{array}{c}\text { S6 } \\
(\text { Group 2) }\end{array}$ & $\begin{array}{c}\text { S5 } \\
(\text { Group 1) }\end{array}$ \\
\hline $\begin{array}{l}\text { Visual } \\
\text { perception }\end{array}$ & good & $\begin{array}{l}\text { average- } \\
\text { good }\end{array}$ & good & good & $\begin{array}{l}\text { average - } \\
\text { good }\end{array}$ & average \\
\hline $\begin{array}{l}\text { Reading } \\
\text { (average \%) }\end{array}$ & 86 & 75 & 76 & 78 & 18 & 17 \\
\hline $\begin{array}{l}\text { Level of } \\
\text { functioning }\end{array}$ & $\begin{array}{c}\text { mild } \\
\text { cognitive } \\
\text { impairment }\end{array}$ & $\begin{array}{c}\text { mild } \\
\text { cognitive } \\
\text { impairment }\end{array}$ & $\begin{array}{c}\text { mild } \\
\text { cognitive } \\
\text { impairment }\end{array}$ & $\begin{array}{c}\text { mild } \\
\text { cognitive } \\
\text { impairment }\end{array}$ & $\begin{array}{l}\text { mild } \\
\text { cognitive } \\
\text { impairment }\end{array}$ & $\begin{array}{c}\text { mild } \\
\text { cognitive } \\
\text { impairment }\end{array}$ \\
\hline $\begin{array}{l}\text { Level of } \\
\text { functioning: } \\
\text { IQ Score }\end{array}$ & 59 & 64 & 50 & 52 & 64 & 63 \\
\hline $\begin{array}{l}\text { Receptive } \\
\text { language } \\
\text { (months) }\end{array}$ & $\begin{array}{c}54 \\
i\end{array}$ & 52 & 50 & 60 & 61 & 48 \\
\hline
\end{tabular}


space. Results obtained during the pre-evaluation are provided in Appendix D.

\section{TRAINING MATERIAL AND PROCEDURE}

Blissymbols were selected from Hehner's (1980) "Blissymbols for use" as well as from McDonald's (1989) "Teaching and using Blissymbolics". A total of twenty eight symbols that represent everyday concepts were selected. Eight compound symbols were selected for training during Stage 1 and seven single configuration symbols for training during Stage 2. A total of fifteen symbols plus three practise items (ball, flower and chair) were thus included for training. Symbols for the training phase were selected to include elements of the compound symbols included in the generalization procedure. Ten symbols were carefully selected for the generalization procedure (refer to Appendix C). The aim of this procedure was to determine whether subjects were able to analyze, synthesize and interpret new symbols based on knowledge gained during training. The symbol elements of the stimuli used in the generalization procedure were all introduced during training, but in combination with different elements. Single configuration as well as compound symbols were selected from different word categories (nouns, verbs, adjectives). Single configuration symbols can be defined as symbols that contain only one semantic unit or element, e.g., "house", "wheel" and "cloth". Compound symbols refer to combinations of more than one semantic element to form new meaning. The symbols that were used during training as well as for the generalization procedure are listed in the Appendix.

Pictures and/or objects representing the eighteen symbols (fifteen training plus three practise items) selected for training were used to explain the concepts and to facilitate training. Games and apparatus which included a Bliss-man, Bliss-Electro, a contextual Storyboard, matching symbol-to-picture worksheets, Picture-Your-Bliss

TABLE 3. Tests and material used during the pre-evaluation phase

\begin{tabular}{|c|c|c|c|}
\hline Areas tested & $\begin{array}{l}\text { Person } \\
\text { responsible } \\
\text { for } \\
\text { administering } \\
\text { the tests }\end{array}$ & Tests/material used & Processing of data \\
\hline Reading & $\begin{array}{l}\text { Researcher in } \\
\text { co-operation with } \\
\text { classroom teacher }\end{array}$ & $\begin{array}{l}\text { Flashcards containing words which } \\
\text { had been taught during the year, } \\
\text { were used. } \\
\text { Areas of evaluation: } \\
\text { - class mates' names (recognition } \\
\text { and labelling) } \\
\text { - functional reading (recognition } \\
\text { and labelling) } \\
\text { - sight words (recognition and } \\
\text { labelling) }\end{array}$ & $\begin{array}{l}\text { An average score was determined } \\
\text { which was derived from the results } \\
\text { obtained for recognition as well as } \\
\text { labelling. The percentage referred to } \\
\text { in Table } 2 \text { is thus the mean } \\
\text { percentage recognized and labelled } \\
\text { correctly in the three areas of } \\
\text { evaluation }\end{array}$ \\
\hline Visual & Local & $\begin{array}{ll}\text { - } & \text { Developmental Test of Visual } \\
\text { Perception (Frostig, 1963) } \\
\text { - } \\
\text { Draw-a-man test (Goodenough, } \\
\text { 1926) } \\
\text { - Developmental Test for Visual- } \\
\text { motor Integration (Beery, 1967) } \\
\text { - Subjective evaluation: } \\
* \text { visual memory } \\
* \text { sequencing skills }\end{array}$ & $\begin{array}{l}\text { An average score which included all } \\
\text { of the subtests, was obtained. Visual } \\
\text { perceptual skills were categorized as } \\
\text { good or average-good }\end{array}$ \\
\hline $\begin{array}{l}\text { Level of } \\
\text { functioning } \\
\text { IQ score }\end{array}$ & $\begin{array}{l}\text { School } \\
\text { psychologist of } \\
\text { that particular } \\
\text { district }\end{array}$ & Unknown & $\begin{array}{l}\text { Most of the children were tested in } \\
\text { the year that they turned six. The } \\
\text { year in which the IQ test was } \\
\text { administered is provided in Table } 1 . \\
\text { IQ scores were felt to be current, as } \\
\text { the experiment was conducted in } \\
1993 \text { and most of the IQ tests } \\
\text { performed in } 1991 \text { and } 1992\end{array}$ \\
\hline $\begin{array}{l}\text { Receptive } \\
\text { language }\end{array}$ & Researcher & $\begin{array}{l}\text { Afrikaans translation of } \\
\text { TACL-R (Kritzinger, 1985) } \\
\text { Subtests: } \\
-\quad \text { word classes } \\
- \text { grammatical morphemes } \\
- \text { elaborated sentences }\end{array}$ & $\begin{array}{l}\text { A mean score was derived from the } \\
\text { results obtained on the three subtests }\end{array}$ \\
\hline
\end{tabular}


(Blissymbolics Communication Institute, 1984), dice, puzzles and snap cards were used during the training stage. Colour-coded flash cards of all the symbols were made according to the guidelines provided by McDonald (1989).

A weekly outline of the data collection procedures is provided in Table 4.

Prior to training, a pre-evaluation of various skills (language, speech, visual perception, vision, hearing and reading) was performed (see Appendix D for results). A pilot study was performed prior to the main study in order to test the effectiveness of the procedure and materials. Recommendations were made on the basis of the results of the pilot study. Please refer to Moolman (1994) for a detailed discussion of the results.

The concepts were evaluated on the day before training started. Concepts that were unknown were explained, until the subject(s) reached $100 \%$. A baseline evaluation was also performed on this day in order to determine the subjects' ability to guess the meaning of the symbols.

Training consisted of two stages. Stage 1 concentrated on the training of compound symbols and Stage 2 on the training of single configuration symbols. Compound symbols were trained first, as the researcher wanted to start with two distinct approaches. If single configuration symbols were trained first, the subjects of Group 2's actual orientation towards the compound symbols might have been influenced negatively. The presentation of the seven single configuration symbols was the same for both the analytic and global groups. Presentation of the compound symbols, however, differed.

Training was performed by the researcher on a daily basis for approximately 30 minutes per group. This procedure was continued until the $100 \%$ criterion for each stage was met by all the subjects. Subjects who met this criterion were still included in the training, in order to keep the time without exposure to symbols the same for all subjects. This was an important factor in the re-evaluation procedure. Games and activities were used during each training session. Picture-your-Bliss was used on days 1, 2 and 3 of Stage 1, and only on day 1 of Stage 2 of the training.

Experimental Group 1 (Subjects 3,4,5) was trained by means of a global approach. The global training approach implied visual recognition of the symbol as a whole. No elements or components or the composition of the symbols were explained to the subjects. Experimental Group 2 (Subjects 2,6,7) was trained by means of an analytic approach. All the symbols were thus discussed in terms of their composition, elements and components.

Training of the symbols for both groups included three steps (identification, association and labelling) which can also be referred to as one presentation. The association and labelling steps were exactly the same for both groups. During Step 2 (association) subjects had to match the symbol to the Storyboard picture and/or to the Bliss-man (association within a context). Step 3 , labelling, was done once within the group and then individually, as each individual subject in the group was asked to label the symbol once. The identification process, however, differed for the analytic and the global groups. The identification process for the global group entailed an outline of the visual agreement between the object/picture and the symbol. The symbol together with the picture/object was held up, the visual agreement was pointed out (only for single configuration symbols) and the symbol labelled. During the identification step for Group 2, the symbol was shown to the subjects and labelled. The visual agreement between the real object/picture was pointed out and the different symbol elements were analysed. The meaning of each element was explained and visual agreement of elements. was pointed out, for example, "to spit", contains three elements (mouth, arrow, action indicator), and all three had to be discussed individually. Elements were then synthesized to form a unit again. Subjects of this group were thus guided in their analysis and synthesis of symbols during training and the rationale behind each symbol was explained.

Individual evaluations of each subject's performance on the eight (compound) or seven (single configuration) symbols were performed daily throughout the training period. The aim of this evaluation was to determine progress and to determine when the criterion $(100 \%$ correct identification of symbols) was met.

Directly after the training (in other words, as soon as all the candidates in the group had met the criterion of $100 \%$ correct identification of symbols), the generalization procedure was administered. The objective of this evaluation was to determine whether the subjects were able to generalize information they had already been taught to new symbols. A non-verbal response (pointing) was thus required for this section of the evaluation. A choice of one out of three unfamiliar symbols that have visual correspondence (a similar semantic element) had to be made (one stimulus item and two distractors). (Please refer to Appendix C for symbols.)

One month after the generalization procedure, subjects' ability to recall the fifteen symbols taught during training was assessed. A one month time period was selected to coincide with the school holidays. During the four week holiday, subjects had no exposure to Blissymbols. The same procedure as that used during daily evaluations was followed in this re-evaluation.

TABLE 4. Weekly outline of the data collection procedures

\begin{tabular}{|c|l|l|l|l|l|}
\hline $\begin{array}{l}\text { Weeks 1 } \\
\text { and 2 }\end{array}$ & Week 3 & $\begin{array}{l}\text { Week 4, } \\
\text { day 1 }\end{array}$ & $\begin{array}{l}\text { Rest of Week 4, } \\
\text { Week 5 and 6 (12 } \\
\text { days of training) }\end{array}$ & Day 13 & $\begin{array}{l}\text { One month } \\
\text { following the } \\
\text { generalization } \\
\text { procedure }\end{array}$ \\
\hline Pre-evaluation & $\begin{array}{l}\text { Pilot } \\
\text { study }\end{array}$ & $\begin{array}{l}\text { Concept and } \\
\text { baseline } \\
\text { evaluations }\end{array}$ & $\begin{array}{l}\text { Training of compound } \\
\text { symbols: 10 days } \\
\text { Training of single } \\
\text { configuration symbols: } \\
\text { days }\end{array}$ & $\begin{array}{l}\text { Administering of } \\
\text { generalization } \\
\text { procedure }\end{array}$ & $\begin{array}{l}\text { Administering } \\
\text { of re-evaluation } \\
\text { procedure }\end{array}$ \\
\hline
\end{tabular}




\section{RESPONSE DEFINITIONS}

A verbal response was expected during the daily evaluations and the re-evaluation procedure in order to eliminate guessing, but a non-verbal response (pointing) during the generalization procedure. Responses were scored as correct $(\bullet)$ or incorrect $(/)$, and the subject's incorrect responses were also recorded during training, the re-evaluation and generalization procedures. A response was regarded to be incorrect if the subject did not know the answer or gave the wrong answer. Symbols that were identified incorrectly were repeated once at the end of the evaluation session to provide the subjects with another opportunity to respond (in both daily evaluations and the reevaluation procedure).

\section{DATA ANALYSIS}

At the beginning of each training session, the exact time was recorded in order to ensure that sessions did not exceed 30 minutes. Directly after the training session, the researcher recorded the length of time that the session had lasted (in minutes) as well as the number of presentations for that particular session. "Number of presentations" refers to the number of times that the individual symbols were identified, associated with the pictures and labelled by the researcher and/or subjects. "Minutes of training" refers to the total number of minutes that were required in order to reach the criterion of $100 \%$ correct identification of all the symbols. Subjects were then evaluated individually. Responses were recorded verbatim and responses were scored as either correct or incorrect. A raw score was therefore obtained. A percentage was calculated

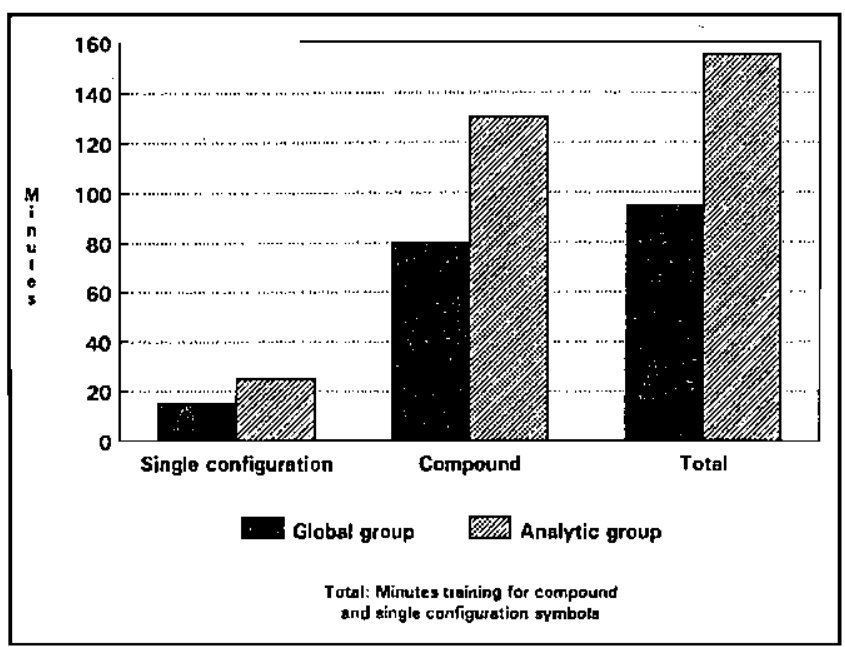

FIGURE 1: Results obtained during training: length of training in order to determine whether the criterion had been met. This procedure was followed for each training session until the criterion was met. After training, the number of presentations and number of minutes that each subject required to fulfil the criterion for each stage (first the compound symbols and then the single configuration symbols) were calculated. A mean percentage for the global and analytic groups was then calculated for each stage.

For the generalization and re-evaluation procedures, responses were once again scored as either correct or incorrect and the subject's responses were written down. Following the calculation of a raw score, a percentage for each individual subject was once again calculated, as was a mean percentage for the global and analytic groups.

Results obtained were firstly analysed in terms of a comparison between the global and analytic groups. A qualitative error analysis was then performed in order to determine the nature of the subjects' errors and difficulties.

\section{RESULTS}

\section{A COMPARISON OF THE RESULTS OF THE GLO. BAL TRAINING METHOD GROUP AND THE ANA- LYTIC TRAINING METHOD GROUP}

The results obtained by Group 1 and 2 during training are presented graphically in Figures 1 and 2.

- The results shown in Figures 1 and 2 clearly indicate that Group 1 required fewer minutes of training to fulfil the criterion for both the single configuration and compound symbols. Group 1 required 95 minutes to learn all 15 symbols, whereas Group 2 required 155 minutes. Thus there is a difference of 60 minutes. Although Group 2 re-

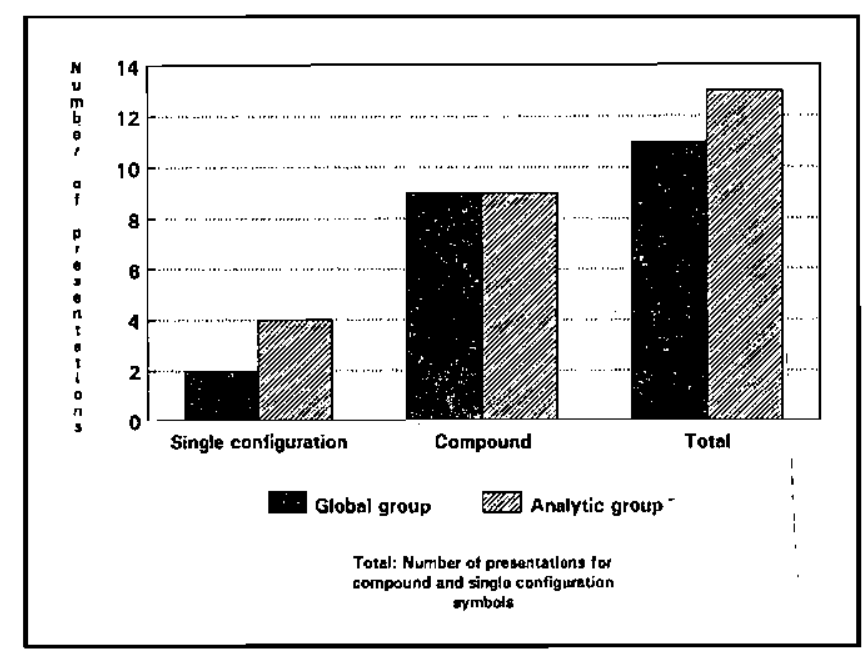

FIGURE 2: Results obtained during the generalization procedure

TABLE 5. Results obtained during the generalization procedure

\begin{tabular}{|l|c|c|c|c|}
\hline \multirow{2}{*}{} & \multicolumn{2}{|c|}{$\begin{array}{c}\text { Group 1 (Subjects trained } \\
\text { through global training approach) }\end{array}$} & \multicolumn{2}{c|}{$\begin{array}{c}\text { Group 2 (Subjects trained through } \\
\text { analytic training approach) }\end{array}$} \\
\cline { 2 - 5 } & Raw scores & Percentages & Raw scores & Percentages \\
\hline Individual raw scores & $6,6,6$ & $7,6,7$ & & \\
\hline Mean scores and percentages & $18 / 30$ & $60 \%$ & $20 / 30$ & $66,7 \%$ \\
\hline
\end{tabular}


The Teaching of Blissymbols as a Bridge into Literacy presentations for both groups to learn the compound symbols was the same ( 9 presentations). Group 1 , on the other hand, required fewer presentations for the single configuration symbols than Group 2 (2 vs 4 presentations).

Results obtained during the generalization procedure are presented in Table 5 .

In Table 5 it is interesting to note that Group 2 performed slightly better in the generalization procedure, with a mean of $66,7 \%(20 / 30)$, compared to Group 1's $60 \%$ (18/ 30 ). All the subjects in Group 1 obtained a raw score of $6 /$ 10 , whereas two subjects from Group 2 scored $7 / 10$ and the third subject scored $6 / 10$.

Results obtained during the re-evaluation procedure are presented in Table 6. As Table 6 indicates, Group 2 also performed slightly better than Group 1 on the re-evaluation procedure. Group 2 obtained a mean of $97,8 \%$ (44/45), whereas Group 1 remembered 91,1\% (41/45) of the symbols correctly. Three subjects, two from Group 2 and one from Group 1, remembered all the symbols and scored $100 \%$.

\section{ERROR ANALYSIS}

A qualitative error analysis has been performed in order to determine the nature of the subjects' substitutions and difficulties in the three phases (training, re-evaluation and generalization procedures). Ease of acquisition was one of the areas of interest. It was scored in terms of number of presentations. During the training phase some symbols were acquired with greater ease than other symbols and differences in the performances of the two groups in terms of ease of acquisition were noted. The results are outlined in Table 7.

TABLE 6. Results obtained during the re-evaluation procedure

\begin{tabular}{|l|c|c|c|c|}
\hline \multirow{2}{*}{} & \multicolumn{2}{|c|}{$\begin{array}{c}\text { Group 1 (Subjects trained } \\
\text { through global training approach) }\end{array}$} & \multicolumn{2}{c|}{$\begin{array}{c}\text { Group 2 (Subjects trained through } \\
\text { analytic training approach) }\end{array}$} \\
\cline { 2 - 5 } & Raw scores & Percentages & Raw scores & Percentages \\
\hline Individual raw scores & $13,15,13$ & & $15,14,15$ & \\
\hline Mean scores and percentages & $41 / 45$ & $91.1 \%$ & $44 / 45$ & $97,8 \%$ \\
\hline
\end{tabular}

TABLE 7. An error analysis of the results obtained during the training phase

\begin{tabular}{|c|c|c|c|c|}
\hline & \multicolumn{2}{|c|}{$\begin{array}{l}\text { Group } 2 \text { (Analytic } \\
\text { training method) }\end{array}$} & \multicolumn{2}{|c|}{$\begin{array}{c}\text { Group } 1 \\
\text { (Global training method) }\end{array}$} \\
\hline & Symbol & $\begin{array}{l}\text { Mean number } \\
\text { of presentations }\end{array}$ & Symbol & $\begin{array}{l}\text { Mean number } \\
\text { of presentations }\end{array}$ \\
\hline \multicolumn{5}{|l|}{ Compound symbols } \\
\hline \multirow{2}{*}{$\begin{array}{l}\text { Symbols most } \\
\text { difficult to acquire }\end{array}$} & to smell & 5 & to fly & 6 \\
\hline & rain & 5 & & \\
\hline \multirow{3}{*}{$\begin{array}{l}\text { Symbols easiest to } \\
\text { acquire }\end{array}$} & to dance & 1.6 & to dance & 2 \\
\hline & bath & 1.6 & bath & 2.6 \\
\hline & to fly & 1.6 & & \\
\hline \multicolumn{5}{|c|}{ Single configuration symbols } \\
\hline \multirow{7}{*}{$\begin{array}{l}\text { Symbols easiest to } \\
\text { acquire }\end{array}$} & house & 2 & house & 2 \\
\hline & ear & 2 & ear & 2 \\
\hline & wheel & 2 & wheel & 2 \\
\hline & cloth & 2 & cloth & 2 \\
\hline & table & 2 & table & 2 \\
\hline & eye & 2 & eye & 2 \\
\hline & & 2 & room & 2 \\
\hline $\begin{array}{l}\text { Symbols most } \\
\text { difficult to acquire }\end{array}$ & room & 2.7 & & \\
\hline
\end{tabular}


Group 2 experienced most difficulty with the symbols "to smell" and "rain". A mean of 5 presentations was required to fulfil the criterion. Group 2 acquired the symbol "to fly" with great ease, requiring a mean of 1.6 presentations, whereas Group 1, by contrast, experienced the greatest difficulty with this symbol, requiring a mean of 6 presentations. Similarities were, however, also noted. The symbols "bath", "to dance" and "to fly" were acquired first by Group 2 with a mean of 1.6 presentations. Group 1 also acquired the symbol "to dance" first, with a mean of 2 presentations, followed by "bath" (mean of 2.6 presentations). The symbols "happy", "to smell" and "rain" were acquired only in the later stages of training in both groups. All the single configuration symbols were acquired with the same degree of ease by Group 1, requiring a mean of 2 presentations. One subject from Group 2, however, experienced difficulty with the acquisition of the symbol "room" and therefore a mean of 2.7 presentations were required by Group 2 to fulfil the criterion.

A qualitative analysis of subjects' responses during the generalization procedure revealed a number of interesting points. The results are outlined in Table 8.

Group 2 scored the lowest ( $0 \%$ ) for the symbols "to cry" and "sad" and scored $100 \%$ for the symbols "to hear", "bathroom", "garage", "aeroplane" and "low". 66,7\% of the group was able to recognise "table cloth" and "legs" and 33,3\% recognised "to jump".

Group 1 scored the lowest for the symbol "sad" $(0 \%)$ and the highest for the symbol "to hear" $(100 \%)$. Only $33,3 \%$ were able to identify "to jump" and "legs", and 66,7\% were able to identify the rest of the symbols ["garage", "bath- room", "low", "to cry", "aeroplane", "to dance"].

Similarities and differences were once again noted in the performances of the two groups during the generalization procedure. Both groups scored $100 \%$ for the symbol "to hear" and scored 0\% for the symbol "sad". The symbols "bathroom", "garage" and "aeroplane" were identified correctly by most of the subjects of both groups, as Group 2 scored $100 \%$ and Group $166,7 \%$ correct identification.

Table 9 provides the results of the re-evaluation procedure for the different word classes as well as the different symbols.

During the re-evaluation procedure, Group 2 scored a mean of $96,3 \%$ for nouns, as opposed to $100 \%$ for verbs and adjectives. Group 1 remembered $88,9 \%$ of the nouns, $100 \%$ of the adjectives and $91,7 \%$ of the verbs. Group 2 thus performed better than Group 1 for nouns as well as for verbs. Group 2 thus remembered $100 \%$ of the compound symbols and $85,7 \%(6 / 7)$ of the single configuration symbols. During the re-evaluation of Group 2 , only subject 6 responded incorrectly once, as he did not remember the noun "cloth" (single configuration symbol). Subjects from Group 1 responded incorrectly to the symbols representing the following nouns: "room", "wheel" (single configuration symbols), "rain" (compound symbol) and also to the verb "to spit" (compound symbol). Group 1 remembered $71,4 \%(5 / 7)$ of the single configuration and $75 \%(6 / 8)$ of the compound symbols.

The qualitative error analysis furthermore revealed that the subjects of both groups remembered more compound than single configuration symbols after a period without any exposure to the symbols. Symbol reduction

TABLE 8. An error analysis of the results obtained during the generalization procedure

\begin{tabular}{|c|c|c|c|}
\hline $\begin{array}{l}\% \text { Correct (from lowest to } \\
\text { highest score) } \\
\text { score) }\end{array}$ & $\begin{array}{c}\text { Group } 2 \\
\text { (Analytic training } \\
\text { method) }\end{array}$ & $\begin{array}{r}\text { Grot } \\
\text { (Global t } 1 \\
\text { metl }\end{array}$ & \\
\hline \multirow{2}{*}{$\begin{array}{l}\text { Lowest score: } \\
0 \%\end{array}$} & sad & \multicolumn{2}{|l|}{ sad } \\
\hline & to cry & & \\
\hline \multirow[t]{2}{*}{$33,3 \%$} & to jump & to jump & . \\
\hline & & legs & ' \\
\hline \multirow[t]{6}{*}{$66,7 \%$} & table cloth & garage & ' \\
\hline & legs & bathroom & 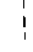 \\
\hline & & low & , \\
\hline & & to cry & \\
\hline & & aeroplane & \\
\hline & & to dance & ' \\
\hline \multirow{5}{*}{$\begin{array}{l}\text { Highest score: } \\
100 \%\end{array}$} & to hear & to hear & \\
\hline & bathroom & & \\
\hline & garage & & \\
\hline & aeroplane & ' & \\
\hline & low & & \\
\hline
\end{tabular}


TABLE 9. An error analysis of the results obtained during the re-evaluation procedure: word classes and symbols

\begin{tabular}{|c|l|c|c|}
\hline \multicolumn{2}{|c|}{} & \multicolumn{2}{|c|}{ \% Correct } \\
\cline { 3 - 4 } \multicolumn{2}{c|}{} & $\begin{array}{c}\text { Group 2 } \\
\text { (Analy tic training } \\
\text { method) }\end{array}$ & $\begin{array}{c}\text { Group 1 } \\
\text { (Global training } \\
\text { method) }\end{array}$ \\
\hline \multirow{2}{*}{$\begin{array}{l}\text { Word } \\
\text { classes }\end{array}$} & Nouns & 96,3 & 88,9 \\
\cline { 2 - 4 } & Verbs & 100 & 91,7 \\
\cline { 2 - 4 } & Adjectives & 100 & 100 \\
\hline \multirow{2}{*}{ Symbols } & $\begin{array}{l}\text { Single } \\
\text { configuration } \\
\text { symbols }\end{array}$ & 85,7 & 71,4 \\
\cline { 2 - 4 } & $\begin{array}{l}\text { Compound } \\
\text { symbols }\end{array}$ & 100 & 75 \\
\hline
\end{tabular}

was noted within Group 2 during training, as subjects often only remembered one element and responded accordingly. Indicators were also often ignored by this group. During the generalization procedure, the subjects of both groups scored $100 \%$ correct identification for the symbol "to hear", and $0 \%$ correct identification for the symbol "sad". Group 2 also scored $0 \%$ for the symbol "to cry".

\section{DISCUSSION}

From the above results it is clear that Group 2 required much more time (in minutes) during the training-phase to reach the criterion of $100 \%$. The main reason for this is most probably the nature of the teaching strategy. The teaching strategy used involves three steps, namely identification, association and labelling. These three steps can also be referred to as "one presentation". Only the identification process differs for the two groups and led to the longer training period for Group 2. The length of training obviously has important implications, particularly for educators and clinicians. Time is a very important factor in the lives of the handicapped. A lot of time goes into therapy and very little time is left over for educational programs (Light \& Kelford Smith, 1993; Smith, 1992). The implication is therefore that clinicians/educators often choose the approach which takes least time, as opposed to an approach which takes much longer,i but gives the same initial results. This is supported by literature on the teaching of reading (Greyling \& Joubert, 1989). Colheart (in Blau, 1988) suggested that the two routes to reading operate parallel to each other, but that the direct visual route (global approach) is a faster method for lexical access than the indirect visual route (analytic approach). Many teachers therefore prefer a global approach to an analytic approach due to the shorter teaching time. However, the hypothesis can be argued that the time required for training (teaching strategy) is reduced the longer the subjects are exposed to Blissymbols. The reason for this is that more symbols and elements are already known and therefore require less/no explanation, as well as the fact that subjects might be more familiar with the processes of analysis and synthesis. Light and Lindsay (1991) refer to this as "automaticity". According to these researchers the cognitive operations become fully automatized with repeated practise, and as a result they no longer require attentional resources and hence do not use up any of the limited space in working memory. What is clear, however, is that a criterion of $100 \%$ correct identification of symbols does not necessarily imply that the skills of analysis and synthesis are established. Educators need to help cognitively impaired children more (and in other ways) with the transfer of these skills. One possibility could be to combine symbol elements with a variety of other symbol elements in as many contexts as possible, for example, "house" + "wheel"; "house" + "animal"; "house" + "envelope", etc. In other words, the number of different recurrent elements should be increased in a variety of contexts.

The finding that Group 2 required more time to reach the criterion does not necessarily imply that these subjects experienced more difficulty in acquiring the symbols. The ease of acquisition (scored in terms of number of presentations) for compound symbols was the same for both groups. In terms of ease of acquisition of compound symbols, the one method therefore did not seem to be more effective than the other. In fact, Shepherd and Haaf (1992) found that their non-disabled subjects trained using the composite meaning method (the analytic approach) required fewer trials for learning than those subjects trained via whole symbol memorization (the global approach). It therefore appeared to be easier for subjects to learn Blissymbols when trained to their component elements. One must bear in mind, however, that results obtained by non-disabled individuals cannot be applied uncritically to cognitively impaired individuals. It is worth noting that Group 1 in this study required a smaller number of presentations to reach the criterion for the single configuration symbols ( 2 vs 4 presentations), but this observation alone was not the main reason for the noticeable difference in the length of training required by the two groups. One has to conclude that the methodology or teaching strategy of the analytic approach is the main factor/cause for the longer training period required. It is important to note that the subjects of Group 2 initially (day 1 of training) seemed overwhelmed by the different components/elements and therefore scored less well than Group 1. On day 2 , however, they scored much better and the difference between the two groups' performances was much smaller. This might be explained by the complexity of 
Blissymbols. According to Luftig and Bersani (1985), it appears that component complexity may initially confuse a naive learner as he/she struggles to learn a new list of unfamiliar symbols. These researchers, however, mentioned that the effects of component complexity are reduced as the learner becomes more familiar and has to link the symbols with a new set of responses. According to Luftig and Bersani (1985), clinicians should introduce the less complex symbols first, until the learner is familiar with the nature of the system. In this study, however, compound symbols were introduced first in order to differentiate clearly between the two stages and the two distinct training strategies. It was felt that training single configuration symbols first would influence the subjects of Group 2's orientation to an analytic approach. At this stage it is uncertain whether this aspect has influenced the results of the study or not, as the study had no control group. It is, however, clear that all the subjects, particularly those of Group 1, acquired the single configuration symbols with real ease, requiring only 2 presentations to fulfil the criterion (4 presentations for Group 2).

An important difference was noted in the performance of the two groups during the re-evaluation and generalization procedures. The results of this study, as well as of that of Shepherd and Haaf (1992), suggest that subjects trained by means of an analytic approach benefitted more in the long term than those trained by means of a global approach. The results of this study indicate that there are no major differences between the two groups' performances, but that Group 2 consistently tended to perform better on the re-evaluation and generalization procedures. Consequently, this phenomenon suggests that the analytic approach has long-term benefits. In the selection of a teaching approach for the teaching of Blissymbols, the long-term effects must definitely be considered. Group 2 performed slightly better than Group 1 on the re-evaluation procedure. Whatever advantages were gained in the analytic training approach were maintained over the one month period without training. This confirms Shepherd and Haaf's (1992) research, as they also found that their nondisabled subjects trained by composite meaning (analytically) out-performed subjects trained via whole symbol memorization (global approach) in the re-evaluation phase. This raises the question as to why Group 2 remembered the symbols better, but did not necessarily learn them faster than Group 1. Schlosser and Lloyd (1992) postulated that it is possible that acquisition and retention require different skills. "Hypothetically speaking, acquisition testing may have been mastered primarily through immediate recall, while retention testing may have required more reliance on an analysis of the cues provided (compound Blissymbols) on the testboards" (Schlosser \& Lloyd, 1992:25). An analytic training approach may have facilitated the analysis of these cues as well as aided recognition memory. If a child only remembers the element “ bread" in the compound "toast", for example, he might be able to extrapolate the other elements and the combined meaning or make a good guess (Schlosser \& Lloyd, 1992). An alternative explanation for Group 2's better performance on the re-evaluation procedure might be that the subjects understood the logic behind the symbols, and because they knew the different elements, it was easier for them to remember the symbols. For Group 1, it was merely a visual symbol that they had to memorize, with no logic behind the symbols. That could also explain why subjects of Group 1 substituted symbols such as "rain", with "to fly" and "to smell", and the symbol "to spit", with "to dance" and "flower". There was no correlation between the actual symbol and the substitute symbols (in terms of elements) - it seemed as if they rather relied on guessing and thus showed limited coping skills.

Results also indicate that the subjects from Group 2 did slightly better on the generalization procedure. This also confirms Shepherd and Haaf's (1992) study. They found that subjects who were trained via the composite meaning method (analytic approach) were able to generalize symbol knowledge more effectively than subjects trained via whole symbol memorization (global approach). Johnsen and Jennische (in McNaughton, 1993) suggested that the processing skills of segmenting and sequencing that a child develops by using Type 2 symbols (such as sequenced ideographic Blissymbols) can help prepare the child for the processing of print. An analytic training approach therefore equips the child with the potential to transfer these skills to novel symbols.

The difference between the two groups' performances was small, and thus statistically insignificant, and this raises the question of why the differences were not more marked. One factor could be that the skills of analysis and synthesis were not totally established and carried over. Although some of the subjects knew all the different components of each of the training symbols, they were not ready to transfer these skills to novel symbols. They were, however, able to do so in most of the cases and were well on their way to achieving these skills. A longer training period would probably have helped the individuals with the transfer of these skills.

A qualitative error analysis led to a few interesting observations with regard to the acquisition, retention and generalization of specific symbols. These are discussed briefly.

According to many researchers (Bloomberg, Karlan \& Lloyd, 1990; Blackstone, 1990), translucency seems to have a positive effect on learning when individuals are learning to pair an already familiar spoken word with a symbol. Iconic symbols are easier to learn because most iconic symbols represent concrete objects/entities (Blackstone, 1990). It is therefore not surprising that the single configuration symbols were learned by both groups after a smaller number of presentations than the compound symbols. However, single configuration symbols were not retained better than the compound symbols by either group. With the re-evaluation procedure, Group 2 only had one symbol wrong, namely "cloth" (doek). Group 1 also remembered more compound symbols than single configurations. Although a number of reasons are possible, the two main reasons that contributed to this phenomenon would appear to be the level of possible visual discrimination and component complexity.

"Visual discriminability" (in other words, when a group of related symbols appear very similar with only minor differences) could have played a role in the results that were obtained. Musselwhite and Ruscello (1984) reported that the "discriminability" of the symbols can pose a possible identification (and, it seems in this case, retention) problem.

In an informal analysis, Schlosser and Lloyd (1992) found that the number of elements in compounds does not correlate with the degree of acquisition when elements are pretaught (analytic approach). However, the number of 
elements in compounds seems to correlate negatively with the degree of acquisition when compounds are taught directly (global approach). In other words, the fewer elements in a compound, the better the degree of acquisition if a global training approach is used (Schlosser \& Lloyd, 1992). This could explain why Group 1 required only 2 presentations in the acquisition of single configuration symbols, versus Group 2's 4 presentations.

To summarize: no major differences between the two training groups' performances were noted, but there was a definite tendency for Group 2 to perform better on the re-evaluation and generalization procedures.

\section{CONCLUSIONS}

The purpose of the study was to compare two training approaches (global vs analytic) in the learning of Blissymbols by mildly cognitively impaired subjects. The following results were obtained: A slight difference between the two groups' performances in all the areas was noted. Group 2 consistently tended to perform better in the reevaluation and generalization procedures. One could hypothesize that if the training period were to be continued, even stronger gains could have been made by Group 2 . The analytic training approach, however, was much more time-consuming than the global approach. The two groups required almost the same number of presentations to fulfil the criterion (with Group 1 requiring two presentations less than Group 2) and therefore one can conclude that the ease of acquisition was similar for both groups. A qualitative analysis reveals that compound symbols are retained better over a one month period without any exposure than single configuration symbols are. Individual variations were noted throughout training. Subjects experienced specific problems with the generalization of some of the symbols, such as "to cry" and "sad", but then again acquired other symbols such as "bath" / "to dance" with relative ease. One can thus conclude that mildly cognitively impaired subjects are able to learn Blissymbols by means of either an analytic approach or a global approach, but that individuals seemed to benefit more from an analytic approach. More emphasis should, however, be placed on the teaching of indicators and abstract elements. Whether or not these conclusions extend to individuals with more severe levels of cognitive impairment is subject to further inquiry.

This study confirmed that Blissymbols can be taught successfully to the mildly cognitively impaired child through either a global and/or an analytic approach. Although there was only a slight difference between the two groups' performances during training, there was a consistent tendency for Group 2 to perform better than Group 1 in the re-evaluation and generalization procedures. This study thus provides initial data to suggest that the training of Blissymbols through an analytic approach provides advantages in the retention of symbols as well as with regard to the generalization to new symbols.

As cognitively impaired individuals may experience problems with analysis and synthesis, the use of an analytic approach to help such children to cope with these skills in relation to normal orthography is important. Also, if one considers the benefits that an analytic approach offers, in that it prepares the child to cope with the processes of analysis and synthesis which are required to learn normal orthography by means of a phonetic approach, the analytic approach seems to be preferable. One should, however, not see Blissymbol teaching as an either/or approach, but one should rather try to balance long- and short-term goals and teach whatever is needed (whether this is pictographic/single configuration or compound symbols) (Schlosser \& Lloyd, 1992). This recommendation is also in line with the suggestion made by Ehri (in Gough, Ehri \& Treiman, 1992) to use a combined approach rather than an either/or approach in teaching reading.

\section{REFERENCES}

Alant, E. (1994). The use of Blissymbols as a first step into literacy with four children with Down syndrome. The South African Journal of Communication Disorders, 41, 23-32.

Archer, L.A. (1977). Blissymbolics - a nonverbal communication system. Journal of Speech and Hearing Disorders, 42, 568579.

Beery, K.E. (1967). Developmental Test for Visual-motor Integration. Cleveland: D.H. Modern Curriculum.

Blackstone, S.W. (Ed.) (1990). Graphic symbols for communication, language and learning. Augmentative Communication News, 3, 1-3.

Blau, A.F. (1988). Fostering literacy development. In: Blackstone, S.W., Cassata-James, E. \& Bruskin, D.M. (Eds), Augmentative Communication: Implementation Strategies. Maryland: ASHA.

Bloomberg K, Karlan, G.R. \& Lloyd, L.L. (1990). The comparative translucency of initial lexical items represented in five graphic symbol systems and sets. Journal of Speech and Hearing Research, 33, 717-725.

Buttery, T.J. \& Creekmore, W.N. (1985). Planning reading instruction for the mildly handicapped child. Reading Improvement, 206-212.

Folk, M.C. \& Campbell, J. (1978). Teaching functional reading to the TMR. Education and training of the mentally retarded $13,322-326$.

Frostig, M.F. (1963). Developmental Test of Visual Perception. California: Palo Alto.

Fuller, D.R. (1992). The effects of translucency, complexity, and response mode on the learning of Blissymbols by preschool children and adults with normal cognitive abilities. Paper presented at ISAAC Conference, Philadelphia.

Goodenough, F.L. (1926). The measurement of intelligence by drawings. London: Harrap.

Gough, P.B., Ehri, L.C. \& Treiman, R. (1992). Reading acquisition. New Jersey: Lawrence Erlbaum Associates.

Greyling, P.J. \& Joubert, J.J. (1989). Didactics: Reading instruction in the junior primary phase. Pretoria: De JagerHaum Publishers.

Hehner, B. (1980). Blissymbols for use. Toronto: Blissymbolics Communication Institute.

Koppenhaver, D.A. \& Yoder, D.E. (1990). Facilitating literacy learning in children with speech and physical impairments. Paper presented at ISAAC Conference, Stockholm, Sweden.

Koppenhaver, D.A., Coleman, P.P., Kalman, S.L. \& Yoder, D.E. (1991). The implications of emergent literacy research for children with developmental disabilities. American Journal of Speech-Language Pathology, 1, 38-44.

Kritzinger, A. 1985. Afrikaans translation of the "Test of auditory comprehension of language II (TACL): Original compiler: Carrow-Woolfolk. Texas: DLM Teaching Resources.

Light, J. \& Lindsay, P. (1991). Cognitive science and augmentative and alternative communication. Augmentative and Alternative Communication, 7, 186-203.

Light, J. \& Kelford Smith, A. (1993). Home literacy experiences of preschoolers who use AAC systems and of their nondisabled peers. Augmentative and Alternative Communication, 9, 10$2 \dot{5}$.

Luftig, R.L. \& Bersani, H.A. (jr). (1985). An investigation of two variables influencing Blissymbol learnability with nonhandicapped adults. Augmentative Alternative Communication, 1, 32-37.

McDonald, E.T. (1989). Teaching and using Blissymbolics. Toronto: Blissymbolics Communication Institute.

McNaughton, S. (1993). Graphic representational systems and literacy learning. Topics in Language Disorders, 13, 58-75.

Miller, L. (1990). The roles of language and learning in the 
development of literacy. Topics in Language Disorders, 10, 124.

Moolman, E. (1994). A comparison of two training approaches in the learning of Blissymbols by cognitively handicapped children. Unpublished M-Logopaedics thesis, University of Pretoria.

Musselwhite, C.R. \& Ruscello, D.M. (1984). Transparency of three communication symbol systems. Journal of Speech and Hearing Disorders, 27, 436-443.

Raver, S.A. \& Dwyer, R.C. (1986). Teaching handicapped preschoolers to sight read using language training procedures. The Reading Teacher, 40, 314-321.

Romski, M.A., Sevcik, R., Pate, J. \& Rumbaugh, D. (1985). Discrimination of lexigrams and traditional orthography by nonspeaking severely mentally retarded persons. American Journal of Mental Deficiency, 90, 185-189.
Schlosser, R.W. \& Lloyd, L.L. (1992). Effects of initial element teaching in a story-telling context on Blissymbol acquisition and generalization. Purdue University, West Lafayette, IN.

Shepherd, T.A. \& Haaf, R. (1992). A comparison of two training methods of Blis-symbols. Paper presented at ISAAC Conference, Philadelphia.

Singh, N.N. \& Singh, J.(1986). Reading acquisition and remediation in the mentally retarded. International Review of Research in Mental Retardation, 14, 165-199.

Smith, M.M. (1992). Literacy and AAC: Methodological issues and research priorities. Paper presented at ISAAC Conference, Philadelphia.

Sterick, G. (1979). A follow-up study of ten children who learned to read in a class for trainable students. Education and training of the mentally retarded, 14, 170-176.

\section{APPENDIX A}

GRAPHIC REPRESENTATION OF SYMBOLS USED DURING TRAINING AND GENERALIZATION PROCEDURES

COMPOUND SYMBOLS USED DURING TRAINING (STAGE 1)

\begin{tabular}{|c|c|}
\hline SYMBOL & $\begin{array}{c}\text { GRAPHIC } \\
\text { REPRESENTATION }\end{array}$ \\
\hline $\mathrm{BAD}(\mathrm{BATH})$ & $\diamond$ \\
\hline REËN (RAIN) & + \\
\hline SPOEG (TO SPIT) & $\omega_{2}$ \\
\hline VLIEG (TO FLY) & $\hat{\therefore}$ \\
\hline DANS (TO DANCE) & $\hat{A} d$ \\
\hline RUIK (TO SMELL) & $\hat{Z}$ \\
\hline BLY / GELUKKIG (HAPPY) & $\dot{0} \uparrow$ \\
\hline HOOG (HIGH) & $\dot{-}$ \\
\hline
\end{tabular}

\section{APPENDIX B}

SINGLE CONFIGURATION SYMBOLS USED DURING TRAINING (STAGE 2)

\begin{tabular}{|l|c|}
\hline SYMBOL & $\begin{array}{c}\text { GRAPHIC } \\
\text { REPRESENTATION }\end{array}$ \\
\hline TAFEL (TABLE) & \ulcorner \\
\hline DOEK (CLOTH) & $\#$ \\
\hline HUIS (HOUSE) & 0 \\
\hline WIEL (WHEEL) & $\bullet$ \\
\hline OOG (EYE) & $\circ$ \\
\hline KAMER (ROOM) & $\sqsupset$ \\
\hline OOR (EAR) & $\ddots$ \\
\hline
\end{tabular}


APPENDIX C

SYMBOLS USED DURING THE GENERALIZATION PROCEDURE

\begin{tabular}{|c|c|c|c|c|c|}
\hline \multicolumn{2}{|l|}{ STIMULUS ITEM } & \multicolumn{2}{|c|}{ ADDITIONAL SYMBOL } & \multicolumn{2}{|c|}{ ADDITIONAL SYMBOL } \\
\hline $\begin{array}{l}\text { TAFELDOEK } \\
\text { (TABLE CLOTH) }\end{array}$ & 丮以 & MAT (CARPET) & 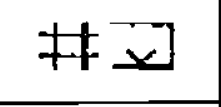 & SERVET (NAPKIN) & 卉9 \\
\hline $\begin{array}{l}\text { MOTORHUIS } \\
\text { (GARAGE) }\end{array}$ & 600 & $\begin{array}{l}\text { POSKANTOOR } \\
\text { (POST OFFICE) }\end{array}$ & & $\begin{array}{l}\text { SKUUR } \\
\text { (BARN) }\end{array}$ & \\
\hline HUIL (TO CRY) & 07 & SLAAP (TO SLEEP) & & $\begin{array}{l}\text { REËNJAS } \\
\text { (RAINCOAT) }\end{array}$ & $7 F$, \\
\hline $\begin{array}{l}\text { BADKAMER } \\
\text { (BATHROOM) }\end{array}$ & $\sqrt{5}$ & $\begin{array}{l}\text { KLASKAMER } \\
\text { (CLASSROOM) }\end{array}$ & 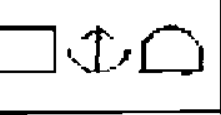 & $\begin{array}{l}\text { EETKAMER } \\
\text { (DININGROOM) }\end{array}$ & o \\
\hline $\begin{array}{l}\text { HOOR } \\
\text { (TO HEAR) }\end{array}$ & & $\begin{array}{l}\text { ASEM } \\
\text { (BREATH) }\end{array}$ & & $\begin{array}{l}\text { BRIL } \\
\text { (CLASSES) }\end{array}$ & $\infty$ \\
\hline $\begin{array}{l}\text { SPRING } \\
\text { (TO JUMP) }\end{array}$ & & $\begin{array}{l}\text { SWAAI } \\
\text { (TO SWING) }\end{array}$ & & $\begin{array}{l}\text { MENG } \\
\text { (TO MIX) }\end{array}$ & \\
\hline $\begin{array}{l}\text { VLIEGTUIG } \\
\text { (AEROPLANE) }\end{array}$ & $\gamma$ & $\begin{array}{l}\text { WA } \\
\text { (WAGON) }\end{array}$ & & $\begin{array}{l}\text { ROLSKAATSE } \\
\text { (ROLLER SKATES) }\end{array}$ & 8 \\
\hline $\begin{array}{l}\text { BENE/VOETE } \\
\text { (LEGS/FEET) }\end{array}$ & & KLIM (TO CLIMB) & & KOM (TO COME) & \\
\hline ONGELUKKIG (SAD) & $\stackrel{v}{c}$ & \begin{tabular}{|l} 
TROOS \\
(TO COMFORT) \\
\end{tabular} & $\stackrel{\hat{T}}{\mathrm{~T}}$ & $\begin{array}{l}\text { VREDE } \\
\text { (PEACE) } \\
\end{array}$ & \\
\hline $\begin{array}{l}\text { LAAG } \\
\text { (LOW) }\end{array}$ & 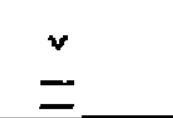 & $\begin{array}{l}\text { DUN } \\
\text { (THIN) }\end{array}$ & $x^{\prime \prime} k$ & $\begin{array}{l}\text { GROOT } \\
\text { (BIG) }\end{array}$ & $\dot{q}$ \\
\hline
\end{tabular}

APPENDIX D

RESULTS OF THE PRE-EVALUATION TEST

\begin{tabular}{|c|c|c|c|c|c|c|}
\hline SUBJECTS & 2 & 3 & 4 & 5 & 6 & 7 \\
\hline AREA ASSESSED: & $\mathrm{AE}$ & $\mathrm{AE}$ & $\mathrm{AE}$ & $\mathrm{AE}$ & $\mathrm{AE}$ & $\mathrm{AE}$ \\
\hline $\begin{array}{l}\text { A. RECEPTIVE } \\
\text { LANGUAGE: (months) } \\
\text { Word classes and relations: }\end{array}$ & $48-51$ & $47-50$ & $51-54$ & $42-44$ & $59-65$ & $45-48$ \\
\hline Grammatical morphemes: & $49-53$ & $58-63$ & $58-63$ & $54-58$ & $46-50$ & $59-65$ \\
\hline Elaborated sentences: & $61-64$ & $71-75$ & $42-45$ & $42-45$ & $71-75$ & $40-43$ \\
\hline $\begin{array}{l}\text { B. AUDITORY } \\
\text { PERCEPTION: } \\
\text { Auditory memory } \\
\end{array}$ & $6,8-6,11$ & $<6,0$ & $8,0-8,3$ & $<6,0$ & $7,4-7,7$ & $<6,0$ \\
\hline Auditory sequencing & $6,0-6,3$ & $6,0-6,3$ & $6,0-6,3$ & $6,8-6,11$ & $6,4-6,7$ & $<6,0$ \\
\hline $\begin{array}{l}\text { Auditory analysis } \\
\text { (Pendulum score) } \\
\text { Subjective evaluation: } \\
\text { *2 syllable words: } \\
\text { *3 syllable words: } \\
\text { *4 syllable words: }\end{array}$ & $\begin{array}{l}5 / 5 \\
3 / 5 \\
1 / 5\end{array}$ & $\begin{array}{l}5 / 5 \\
3 / 5 \\
0 / 5\end{array}$ & $\begin{array}{l}5 / 5 \\
0 / 5 \\
0 / 5\end{array}$ & $\begin{array}{l}5 / 5 \\
3 / 5 \\
1 / 5 \\
\end{array}$ & $\begin{array}{l}5 / 5 \\
5 / 5 \\
0 / 5\end{array}$ & $\begin{array}{l}5 / 5 \\
5 / 5 \\
0 / 5\end{array}$ \\
\hline Auditory closure & $<6,0$ & $<6,0$ & $<6,0$ & $<6,8$ & $<6,0$ & $<6,0$ \\
\hline
\end{tabular}

Die Suid-Afrikaanse Tydskrif vir Kommunikasieafwykings, Vol. 44, 1997 


\begin{tabular}{|c|c|c|c|c|c|c|}
\hline Auditory synthesis & $<6,0$ & $<6,0$ & $<6,0$ & $<6,0$ & $<6,0$ & $<6,0$ \\
\hline Sound blending & 7,7 & 5,3 & 7,1 & 6,2 & 6,8 & 5,3 \\
\hline $\begin{array}{l}\text { C. READING: } \\
\text { Names of classmates: } \\
\text { \% recognized } \\
\text { \% labelled }\end{array}$ & $\begin{array}{c}100 \\
71\end{array}$ & $\begin{array}{c}100 \\
71\end{array}$ & $\begin{array}{l}93 \\
79\end{array}$ & $\begin{array}{l}46 \\
18\end{array}$ & $\begin{array}{l}27 \\
18\end{array}$ & $\begin{array}{l}100 \\
100\end{array}$ \\
\hline $\begin{array}{l}\text { Functional words: } \\
\% \text { recognized } \\
\% \text { labelled }\end{array}$ & $\begin{array}{l}100 \\
100\end{array}$ & $\begin{array}{l}67 \\
44\end{array}$ & $\begin{array}{c}100 \\
75\end{array}$ & $\begin{array}{c}38 \\
0\end{array}$ & $\begin{array}{l}38 \\
25\end{array}$ & $\begin{array}{l}78 \\
56\end{array}$ \\
\hline $\begin{array}{l}\text { Sight words: } \\
\text { \% recognized } \\
\text { \% labelled }\end{array}$ & $\begin{array}{l}67 \\
75\end{array}$ & $\begin{array}{c}100 \\
83\end{array}$ & $\begin{array}{l}67 \\
33\end{array}$ & $\begin{array}{l}0 \\
0\end{array}$ & $\begin{array}{l}0 \\
0\end{array}$ & $\begin{array}{l}67 \\
50\end{array}$ \\
\hline $\begin{array}{l}\text { Average score: } \\
\text { \% word recognition }\end{array}$ & 89 & 89 & 87 & 28 & 22 & 2 \\
\hline $\begin{array}{l}\text { Average score: } \\
\% \text { word labelling }\end{array}$ & 82 & 66 & 63 & 6 & 14 & 69 \\
\hline $\begin{array}{l}\text { D. EXPRESSIVE } \\
\text { LANGUAGE: } \\
\text { Mean length of utterance }\end{array}$ & 6,6 & 2,3 & 5,9 & 5,30 & 6,1 & 4,1 \\
\hline $\begin{array}{l}\text { Predicted chronological } \\
\text { age (months) }\end{array}$ & $>58,3$ & 29,3 & 57,5 & 52,8 & $>58,3$ & 43,4 \\
\hline $\begin{array}{l}\text { Speech intelligibility } \\
\text { (see scale) }\end{array}$ & 5 & 3 & 5 & 5 & 3 & 5 \\
\hline $\begin{array}{l}\text { E. VISUAL PERCEP- } \\
\quad \text { TION RATING: } \\
\text { Average score } \\
\text { (the average score } \\
\text { includes all the subtests } \\
\text { provided below) }\end{array}$ & $\begin{array}{c}\text { good } \\
4,8\end{array}$ & $\begin{array}{c}\text { good } \\
4,4\end{array}$ & $\begin{array}{l}\text { average - } \\
\text { good } \\
4,4\end{array}$ & $\begin{array}{c}\text { average } \\
4,5\end{array}$ & $\begin{array}{c}\text { average } \\
4,3\end{array}$ & $\begin{array}{c}\text { good } \\
4,9\end{array}$ \\
\hline
\end{tabular}

*Key: AE: age equivalent

PS: Although the Test of Oral Language Production was administered, the results are not provided here, as it was thought to be unreliable. Subjects experienced extreme difficulty with story formulation, and were unable to provide a meaningful story most of the time.

Results of the visual perception testing

\begin{tabular}{|l|c|c|c|c|c|c|}
\hline Subtests & $\mathbf{S ~ 2}$ & $\mathbf{S 4}$ & $\mathbf{S 7}$ & $\mathbf{S 3}$ & $\mathbf{S}$ & $\mathbf{S ~ 5}$ \\
\hline Draw-a-man test & 3,6 & 3,9 & 4,6 & 4,3 & 3,6 & 4,0 \\
\hline Visual-motor integration & 3,9 & 3,6 & 4,9 & 4,4 & 4,9 & 4,9 \\
\hline Hand-eye co-ordination & 4,0 & 3,9 & 4,9 & 4,9 & 4,6 & 4,6 \\
\hline Foreground-background & 3,3 & 3,6 & 3,6 & 3,9 & 4 & 3,9 \\
\hline Form consistency & 5,6 & 6,0 & 5,6 & 4,6 & 4 & 4,6 \\
\hline Position in space & 5,0 & 5,0 & 5,0 & 4,9 & 4,9 & 5,6 \\
\hline Spatial relationships & 4,9 & 3,0 & 4,9 & 5 & 4,9 & 4,9 \\
\hline Memory (subjective evaluation) & 8 & 6,0 & 6,0 & 4 & 4 & 5 \\
\hline Sequencing (subjective evaluation) & 5 & 4,6 & 4,6 & 4 & 4 & 4 \\
\hline Total score & 43,3 & 39,6 & 44,1 & 40 & 38,9 & 40,7 \\
\hline Average score & 4,8 & 4,4 & 4,9 & 4,4 & 4,3 & 4,5 \\
\hline
\end{tabular}

